For citation: Kolesnikova, D. M., Noshchenko, O. V. \& Kryukov V. A. (2019). Localization of the Arctic Mining Projects: Norwegian and Russian Experience. Ekonomika Regiona [Economy of Region], 15(4), 1009-1021 https://doi.org/10.17059/2019-4-4

UDC: 332.1

D. M. Kolesnikova a), O. V. Noshchenko a), V. A. Kryukov a, b)

a) National Research University Higher School of Economics (Moscow, Russian Federation)

b) Institute of Economics and Industrial Engineering of the Siberian Branch of RAS (Novosibirsk, Russian Federation; e-mail: kryukov@ieie.nsc.ru)

\title{
LOCALIZATION OF THE ARCTIC MINING PROJECTS: NORWEGIAN AND RUSSIAN EXPERIENCE ${ }^{1}$
}

Localization is regarded as a milestone of economic and social development at national and regional levels since it may contribute to the growth of production capacity. Following the potential of localization, governments of various mining countries resort to such strategic solution aiming to boost the growth of remoted areas such as the Arctic region. However, the implementation of localization strategies, assessment methodology and intermediate consequences vary significantly. Thus, the theoretical underpinnings of localization regarding generation of ripple effects and analysis of current implications are essential are the basis of our research question. Norwegian localization experience is considered as the most successful, while Russian attempts to create local content in the Arctic are frequently criticized. Therefore, we focused on the comparative analysis of Norwegian and Russian localization experience. The study comprises examination of both national and regional levels aiming to reveal key components of success and potential burdens. On national level, the research addresses macroeconomic Input-Output model focused on assessing the cumulative impact and potential of mining industry. On regional level, we conducted analysis of the key socio-economic indicators affected mostly by mining activities as well as their localization. In this regard, we used available statistical microdata. Given the results, the success of localization in remoted regions is determined by intensification of inter-regional links and implementation of the governmental approach towards mining projects focusing on upstream and downstream industries. At the same time, narrow governmental regulation leads to leakage of potential benefits. The research results may contribute to increase of knowledge on localization and ripple effects dynamic. Moreover, they may be considered while developing localization solutions for the Arctic projects.

Keywords: local content regulation, Arctic projects development, ripple effects, localization, regional impact, mining industry, Russia, Norway, value added chain, input-output model, social and economic development

\section{Introduction}

In recent public statements several Russian policy-makers expressed the concerns about the localization of the Artic regions that are still underdeveloped. Despite the adoption of numerous laws and orders by the Russian federal, regional or local authorities aimed to boost economic and social effects from project developed in the Arctic, the benefits generated under such projects are still comparatively small. While foreign successful Arctic projects are based on local or regional production, the projects in Russia are mainly characterised by low involvement of local producers and weak interconnection between economic sectors. Particularly, Russian import of specific machinery and equipment for extraction and processing of mineral resources amounts to more

${ }^{1}$ (c) Kolesnikova D. M., Noshchenko O. V., Kryukov V. A. Text. 2019. than $\$ 6-8$ billion per year ${ }^{2}$, what represents the great share of overall equipment procurement. As exchange rate has gone up, the completion of such projects in Arctic region as Yamal LNG (LNG meaning Liqufied Natural Gas) in Sabetta [1] and Shtockman field development made government to either increase its share of subsidies or postpone the project indefinitely. Yamal LNG costed overall more than $\$ 27$ billion according to official sources $^{3}$ and was launched in December of 2017. Earlier development of Shtockman was stopped because of the shale revolution in the USA in 2012.

Despite the fact that the Arctic is a region with a high resources' development potential, project development there is primarily associated with risks and high level of costs determined by the ex-

\footnotetext{
2 Federal State Statistics Service. Retrieved from: https://eng. gks.ru/ (Date of access: 13.05.2019).

3 Yamalo-Nenets Autonomous District Investment Portal. Retrieved from: http://invest.yanao.ru/?eng=1 (Date of access: 11.05.2019).
} 
treme conditions, remoteness and expensive technologies. At the same time, under the Russian government's strategy, the development of the Arctic projects was supposed to generate positive economic and social effects at regional and national levels. One of the mechanisms, proved by practical examples, is to increase value added created in the national economy by localizing more value chains. In addition, the national macroeconomics is a system of inter-company chains and relations that can lead to either economic and social prosperity or depression. The vector of development depends on policy and measures adopted by the government and local authorities under cooperation with companies. Therefore, any model examples cannot be copied and applied perfectly in different conditions. However, there are still some lessons to be learnt.

\section{Background}

In recent years, it is widely considered that the Arctic region has a huge potential in growth of mineral resources production. The development of the territory is supposed to exert pervasive impact on the economic and social indicators on both national and regional levels [2]. However, the extensional growth (increase in number of mining projects) is not necessarily corresponding to economic and social prosperity. This paradox is also known as the resource curse, which implies that resource-rich countries are less economically developed, and less socially and politically stable comparing to those countries that are not abundant with natural resources $[3,4]$. One of the possible reasons is the change of economic structure during the period of popularity of mineral resources' extraction, which restricted the economic capacity in long-term. In order to minimise negative influence, national and regional authorities should invest into diversification of the economy on both levels. To make this possible, they have to encourage corporate sector to bring more value by building interconnections between sectors. That is why the understanding of this problem was also posed as: «The days when resource companies could simply produce and export a country's resources are long gone, companies need to give host countries more than revenue and royalties» [5]. CEO of Eni, Claudio Descalzi meant that mining projects are required to not only generate direct cash flows in form of taxes and rent revenue for government, and dividends for investors. They should also influence economic and social environment and contribute to the region's development by diversifying the economic structure.
One of the ways to increase benefits for national and regional economy is to multiply the percentage of material and labour costs used in the construction stage and the production process in order to generate extra value added for local economy. Value added may be created anywhere in terms of the territory or structure of economy. However, it is supposed to be a result of the actions in mining projects [6]. This becomes possible due to interlinkages inside the value chain of mining sector [7]: sectors-suppliers that fulfil the mining sector's demand for products and service; and sectors-customers that create a demand for mining sector's output. Unfortunately, the existence of interlinkages between sectors alone does not guarantee that country in general or its mining region would get a significant positive impact from mining projects' development, because mining industry purchases products and services which are either domestically produced or imported. According to World Bank study [8] import is a full leakage, while domestic spending stimulates further demand and increases economic activity. That means that the more investments of mining industry are localized, the larger economic and social effect is provided. Therefore, both interlinkages between sectors and localization of value chain are supposed to have a significant positive effect on economic and social environment of the country and region [9].

According to International Petroleum Industry Environmental Conservation Association (IPIECA) research [9], localization of value chain focuses on national and regional development in the form of: (i) increase of value added of national production in the whole value chain; (ii) construction and modernisation of local production facilities and infrastructure; (iii) demand for local suppliers of products and services; (iv) employment of local workforce, etc.

The aforementioned measures are often implemented as a policy tool, which is aimed at multiplying the economic and social activity. All these forms reflect different incentives for countries' implementation of localization. Developed countries, firstly, were introducing localization for creating additional jobs for the local employees. At the same time, developing countries were more worried about protecting the mining sectors. Thus, they provided local mining companies with foreign and domestic orders for strengthening market position [10]. Localization of value chain is also known as an import substitution policy, which often was opposed to globalization. Globalization as a new after-war global trend nowadays is highly criticised. Some scientists highlight the necessity 
to localize financial crises and other instabilities, when globalization is inevitable [11]. The others say that globalization has increased the imbalances and inequality between the centre and the periphery [12] . Moreover, they claim that saving the boundaries is one of the ways to achieve economic and social prosperity especially when it concerns countries, which are abundant with natural resources.

Some developed countries have learnt how to maximise economic and social effects using the described approach. Returning to considering the Arctic's case, the country of the particular interest is Norway. Norway exploits the Arctic zone's resources for about half of the century in order to increase their economic and social development on the local and national levels. It took several decades to optimise Norwegian economic structure by encouraging local and foreign mining projects operators to introduce specific programs (for example, local content, R\&D and educational programs). They contribute to the government's goal in the framework of localization policy. These measures also caused the growth of social indicators regionally and nationally. For Russia, Norwegian experience is a matter of interest, at least due to the fact that Norway (as well as Russia) has large share of state mining companies participating in the implementation of the Arctic projects. The specific interest of Russian government in Norwegian model of the Arctic development has also been proved by the fact that in 2006, when Russia just started to plan mining projects in the Arctic, workshops and conferences were held for government and business representatives of Russia and Norway aimed at exchanging experience of Finnmark success. Therefore, it is necessary to analyse what is worth learning for Russia from Norway case in terms of national and regional development.

\section{Methodology and Data}

As it was mentioned, the structure of economy as well as localization of value chains effect the economic and social development of the mining country and region. According to this approach, the effects from the sectors' interlinkages and working value chains' mechanism are classified as follows:

(1) financial flows (direct effects) inside the sector, which are represented by taxes, licenses, fines, fees paid by mining sector directly in favour of government; dividends and wages related to the implementation of the project [13];

(2) all flows arising from relations with suppliers and service (backward linkage);
(3) relations with customers (forward linkage).

Backward and forward linkages together are called indirect effect [6].

The sum of direct and indirect effects represents total economic and social effect of the industry. If the definition of direct effects does not cause any challenges, the concepts of indirect or even total effects are rather more sophisticated. In common sense, total effects appear due to economic shock (project, new industry launch, new region development), which multiplies the number of economic activity cycles (cycles of production and consumption) in national and regional economy. In macroeconomic theory, the effect from multiplication of economic activity cycles is represented as a coefficient. The concept of so-called ripple effects (in some resources multiplier effects) has been spread due to J. M. Keynes, who developed it out of the theory of general economic equilibrium. According to Keynes, the indicator describes the relationship between change of all benefits (including financial income, Gross Domestic Product (GDP), Gross Regional Product (GRP) and other positive effects) with regard to another parameter (as a rule, investments or expenses). Investments are considered as a way to allocate resources by sectors of the economy. However, in the conditions of restricted resources and undiversified economy it is also a possibility to direct a large amount of money to import [14].

In the recent years, the interest of ripple effects' estimation has increased. In Russia, it is caused by the necessity to reconsider approach to the strategy of development of new areas such as the Arctic (see above). These areas do have a potential to influence economic and social environment, but the first round of projects in the area has not demonstrated what was expected. One of the most common approaches to assessing the estimation of these effects is Input-Output matrix [15]. Development of this method is associated with the name of Wassily Leontief, who analysed the structure of the U.S. economy by sectors in 1930s. In order to estimate total effect, Leontief introduced mechanism called inverted matrix, which represents a table of total cost coefficients. These coefficients calculated from matrix help to indicate the amount of output by the supplier's industry that is needed to produce one unit of the customer's industry.

In regards to the research question and proposed methodology, this paper examines the input-output table prepared by Institute of national economic forecasting of Russian Academy of Science for Russia and input-output tables prepared by Norway Statistics Agency for Norway. 
The advantages of the method and data applied comparing to others (for example, econometric modelling) is that matrix structure helps to build a model around the relations of sectors-suppliers and sectors-customers. In this way, it is possible to estimate both direct and indirect effects of economic activity's increase. However, this approach has some drawbacks, such as suggestions about linear correlation between sectors of input and output. Moreover, the model is static and raises the problem of data aggregation, which we partly overcame with the help of statistical analysis. As follows from the definition of «multiplier», sometimes even a large multiplier does not imply high ripple effect. The economic sectors may have different weights in the total gross output, so the rate of change in production dynamics, the nominal output growths in different types of activity will differ significantly [16]. Therefore, the results obtained for ripple effects' estimations on the country level are reinforced by regional statistics analysis.

Given the above, the development of ripple effects' analysis based on input-output tables along with review of regional statistical enables us to shed light on the country's differences, existing approaches to localization, and boundaries that hamper economic and social growth.

\section{Country Level Analysis}

Over last several decades there has been no change in the fact that mining industry is a key economic driver for more than two thirds of countries all over the world. However, most of these countries fail to transform their resource endowment into long-term prosperity. McKinsey Global Institute, 2013 [17] brainstormed some core ideas on how to change the existing injustice. They include strengthening of the resource sectors' institutions and governance; developing infrastructure; supporting robust financial policy and market competitiveness, and involving more local content into the distribution of project investments.

In the current research, we focus on the last approach. It is considered that one of the reasons why some resource-rich countries have low level of GDP per capita and other economic and social parameters [4] is that mining sector forms little value added localized in the national economy in both short- and long-term perspectives [3]. It is explained by the specification of the industry, which is not directed to create value because, as a rule, it is placed at the beginning of the value chain [18]. On the other hand, it is supposed to stimulate extra economic activity of sectors-suppliers and sectors-customers and increase their value added [8].
From the localization perspectives, the Norwegian experience is regarded as the most prominent and successful. Russian strategic projects are implemented with the significant support of foreign capital in different forms such as direct investments, suppliers of technologies, machinery and equipment, etc. At the same time, Norwegian current mining projects that are developed, for example, in the Barents Sea, are characterised by lthe evel of localization exceeding $60 \%$ and high indicators of value added (see Figure 1).

Figure 1 is based on information provided by World Integrated Trade Solution database ${ }^{1}$, which collects data of value added across countries and sectors. In terms of database methodology, direct value added shows contribution of a concrete sector to domestic production and/or export. In Figure 1, we compare Russian and Norwegian direct value added of mining sector in percentage to all economic value added. It should be noticed, that value added formed by mining sector in Russia is almost twice smaller than Norwegian value added. The same trend is revealed for two other indicators considering the linkages of the sector with all other sectors of the economy as a customer (forward links) and supplier (backward links). From the definition of localization, it may be concluded that in long term the greater number of value chains is localized, the higher value added is created in the national economy. Therefore, the analysis of direct and indirect value added for Russia and Norway supports the project data, which stated that the Russian mining projects have low level of involvement of national and regional suppliers as contrasted with Norway [19].

It is suggested that the adequate situation for economic and social development is when localization of value chain involves national contractors of such sectors as (1) construction; (2) transportation; (3) research and development; (4) machinery and equipment, and due to new trends of digitalization (5) computer science. They contribute to higher levels of total effect on national economy, in terms of current research, expressed by ripple effects. Moreover, even individually, these sectors usually have large ripple effects for the economy and significantly participate in national prosperity and development.

As follows from the Input-Output table's computations, methodology of which is explained in the previous part, these sectors, indeed, have high rate of ripple effects (see Table 1) in both coun-

\footnotetext{
${ }^{1}$ World Integrated Trade Solution database. World Bank Group webpage: Retrieved from: http://wits.worldbank.org/ (Date of access: 11.05.2019)
} 


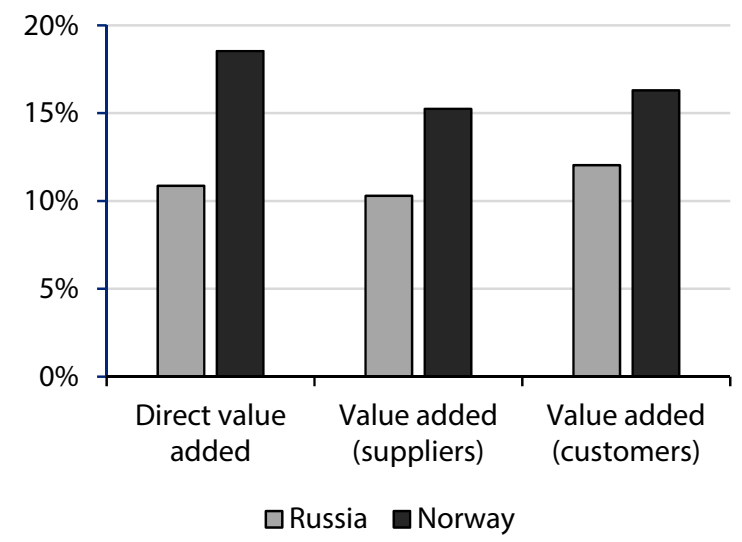

Fig. 1. Direct and indirect value added for Russia and Norway, $\%$

Table 1

Ripple effects by industry for Norway and Russia*

\begin{tabular}{|l|c|c|}
\hline \multicolumn{1}{|c|}{ Industry } & Norway $^{* *}$ & Russia $^{* * *}$ \\
\hline Construction & 8.15 & 5.10 \\
\hline Transportation & 6.29 & 4.13 \\
\hline Mining industry & 3.91 & 3.65 \\
\hline R\&D & 3.59 & 1.91 \\
\hline Machinery and Equipment & 3.57 & 1.69 \\
\hline Computer science & 2.13 & 1.24 \\
\hline
\end{tabular}

* The multipliers were computed by the authors based on symmetric input-output table for domestic production.

${ }^{* *}$ Input-output table prepared by Institute of national economic forecasting of Russian Academy of Science for 2015. Retrieved from: http://macroforecast.ru/index.html (Date of access: 11.05.2019).

*** Input-output tables for 2015 Statistics Norway. Retrieved from: https://www.ssb.no/en/nasjonalregnskap-og-konjunkturer/tables/supply-and-use-and-input-output\#published_23_ August_2018 (Date of access: 11.05.2019).

tries. However, comparing the effects for Russia and Norway we notice that overall effect arising in economy due to increase of economic activity in considered sectors is relatively larger in Norway, despite the difference in the economies' sizes.

Digging dipper into the analysis, it is necessary to consider how the ripple effect of mining sector is distributed by interconnected sectors. Top industries that are subject to positive influence of interaction with mining sector through value chain in Russia include Business services, Chemical production and Energy generation and distribution. The last two are explained by the origin of mining sector. Unfortunately, Research and Development are placed on one of the bottom positions. In contrast, the mining projects in Norway are characterised by large investments in national research activity. Especially, the extraction of hydrocarbons in the Barents Sea is unique and, thus, requires outstanding technological solutions. In this regard, under project development in the High North the operator companies invest large amounts of money into research, including technological and engineering developments of the Norwegian research centres, which are usually localized in the region of the field development. This fact explains top positions of such sectors influenced by mining sector's activity as Machinery and Equipment, and Research and development.

Thus, considering the equal conditions, the overall amount of ripple effects in Norway generated by only one investment project significantly exceeds the same effects observed in the Russian projects' development [20]. The revealed strong links between initial mining sector investments and other sectors of Norwegian economy contribute substantially to the development of gross domestic production and value added due to higher localization. In Russia, the weak communication among different economic sectors as well as among neighbouring regions diminishes the potential positive effects of the projects.

The key explanation of the revealed gap between ripple effects lies in the basic approaches to project development in the considered countries. Despite the focus on national economic growth (based on numerous laws and government acts), in fact, the project's implementation in Russia is characterised by high level of foreign participation in comparison with low engagement of local producers and investors, which results in the low ripple effects' coefficients. The other important lesson to be learnt is the necessity to stimulate local R\&D. In short term, R\&D create additional job positions; in long term, they help to propel national economy due to substitution of imported technologies, machinery and equipment with national ones.

The next section of the article examines economic and social effects induced by development of particular area. At this point, it is worth noting that economic and social benefits assumed to be generated under localization could be regarded and assessed from short (middle)-term or longterm perspectives. The application of the latter approach is limited to analysis of longstanding well-developed projects. Since mining activity in the Arctic is characterised by the most recent emerging projects, for the purposes of the article we analysed mining projects effects from shortand middle-term perspectives.

\section{Region level analysis}

\section{The High North experience of Russia: Yamal- Nenets Autonomous Okrug Overview}

The problem of localization is acknowledged by the Russian authorities. Thus, during last years, the Russian government has increased focus on 
economic and social development of the Artic regions via project development. Following the federal laws, regional development strategies and adopted measures, the focus of the domestic economy shifts towards integral development of industrialised territories of the High North. Based on the government's program regulating economic and social development of the Arctic zone ${ }^{1}$, the emphasis is placed on mining projects as key drivers of regional development. Particularly, as follows from the document, the increase of localization (including production capacities of interconnected industries) may contribute a lot to the regional development. In this regard, mining sector is considered as one of the potential drivers of the High North economy development.

Under Russian Arctic development, the main mining activities took place in the Yamal-Nenets Autonomous Okrug (hereinafter, the «YaNAO»), that is characterised by a significant resource potential, as well as a successful and unique example of processing facilities of the Yamal LNG project built in harsh climate conditions. Except Yamal LNG, there are more than 20 mining investment projects carried out both on- and offshore $^{2}$. The mining and energy projects developed in the YaNAO are quite large in terms of investments and production potential. Therefore, they are expected to make a great contribution to the regional development.

\section{The High North Experience of Norway: Finnmark Overview}

The issue of ripple effects' growth under the Arctic projects is challenging, since such projects are developed far from population clusters and other production facilities. Moreover, usually the regional economy is not well-developed while the local businesses require more expertise and qualification to be involved into technologically advanced mining projects. These factors are regarded as quite reasonable obstacles that negatively affect the projects' impact on local and regional economic and social life.

\footnotetext{
${ }^{1} \mathrm{Ob}$ utverzhdenii gosudarstvennoy programmy «Sotsialnoekonomicheskoe razvitie Arkticheskoy zony Rossiyskoy Federatsii na period do 2020 goda» [Resolution of the Russian Federation Government of 21 April 2014 № 366 «About the statement of Russian Federation state program «Social and economic development of the Arctic zone of the Russian Federation up to 2020» approved by Government of the Russian Federation]. Retrieved from: http://government.ru/docs/11967/ (Date of access: 11.05.2019).

2 Yamalo-Nenets Autonomous Okrug Investment Portal. Retrieved from: http://invest.yanao.ru/?eng=1 (Date of access: 11.05.2019).
}

Nevertheless, the Norwegian government underlines the importance of the development of the High North regions under expensive investment projects that are expected to promote significant economic impulses. In the last decade, the mining activity has intensified in the Norwegian Arctic. Due to technological development, mining companies gained access to enormous oil and gas reserves located in the High North areas of Norway. Hence, the Norwegian government stresses the increasing role of mining projects for the Arctic's economic and social development ${ }^{3}$. The Norwegian approach to the Arctic's growth is based on sustainable business development, and value chains' generation based on local resources and cooperation between academic sphere and business. This approach underlies the efficient development of high-tech mining projects Snøhvit and Goliat in Hammerfest, Finnmark, which atr based on local suppliers' procurement. Considering the Norwegian experience of the Arctic project development, the success of the mining sector in Finnmark (which is not the largest within the regional economy) is worth mentioning, since the related industries of Finnmark are more developed and greater in number of employees.

\section{Comparative Analysis of the Main Economic Indicators}

We analysed the dynamic of the main economic indicators that might be affected by implementation of challenging projects in selected regions of Norway and Russia. For the purposes of the analysis, we applied the index method, which involves comparing analysis of the actual figures of the key indicators of economic development for the regions and their changes over the selected period. The revealed trends are backed by analysis of procurement policy and existing approaches of companies and government towards localizations.

As follows from the statistical analysis, the intensification of mining activity in the YaNAO has led to rapid growth of the main indicators usually describing regional economic development, which is also supported by increase of gross regional product (GRP) of the YaNAO. Currently, the region is one of the leaders in economic growth among other Russian regions. The statistic figures show the unprecedented positive sweeping changes in economic situation of the region, where GRP for 6

\footnotetext{
${ }^{3}$ Norwegian Government Norway's Arctic Strategy, 2-3, 23. Retrieved from: https://www.regjeringen.no/en/dokumenter/ arctic-strategy/id2550081/ (Date of access: 11.05.2019).
} 


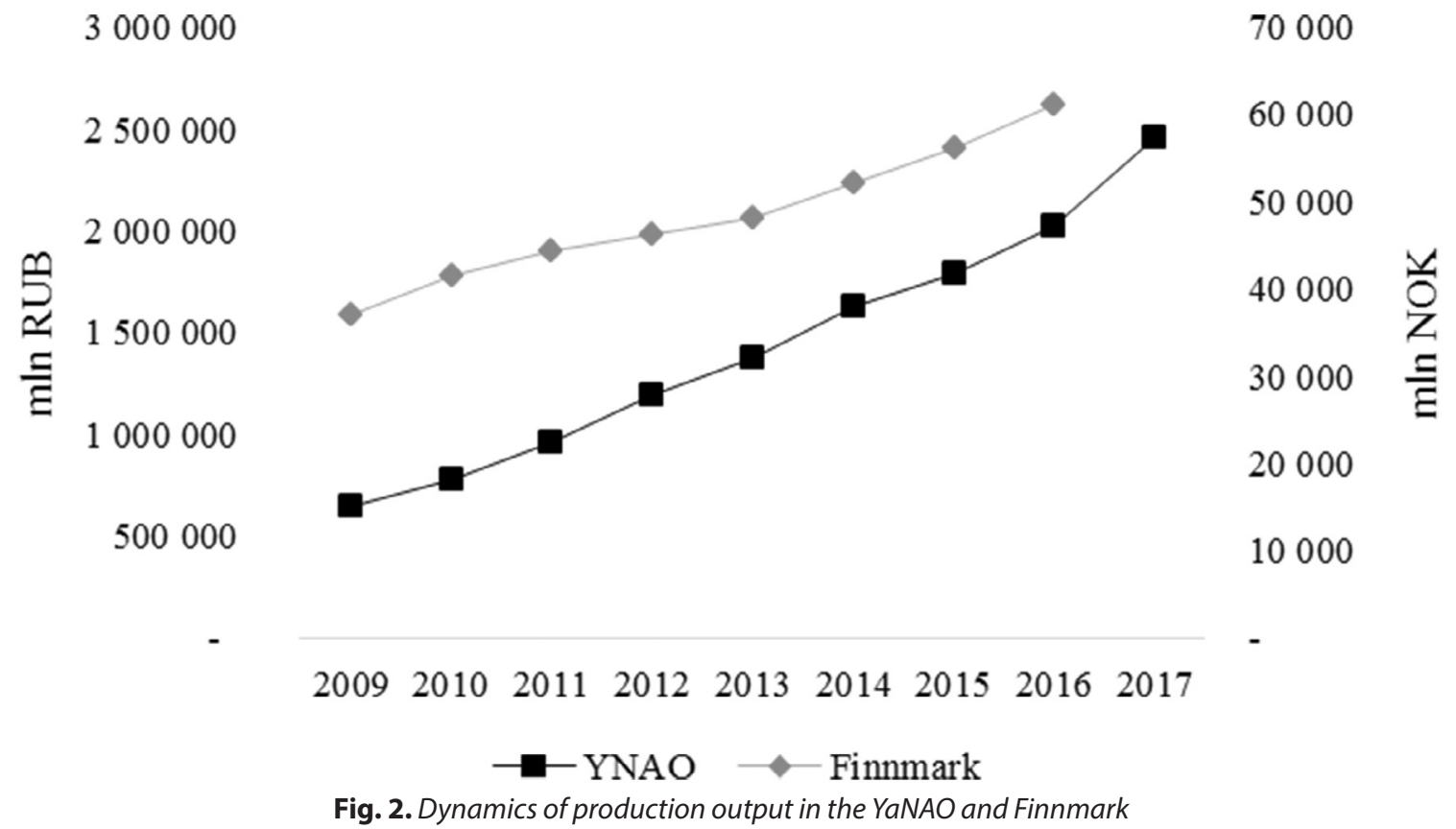

years increased by $151 \%$ in total from 782 to 1,963 mln RUB ${ }^{1}$.

Moreover, in the past few years, the YaNAO has been one of the leading regions with respect to: (1) the amount of investments in fixed assets per capita, (2) industrial output, (3) inflation, and (4) unemployment rates. Particularly, in the last 9 years the YaNAO demonstrated positive dynamics of investments in fixed assets. The total growth of capital investments per capita from 2010 to 2018 increased by $173 \%$. The major input in overall investments in fixed assets in the YaNAO is contributed by mining companies responsible for more than $80 \%$ of all investments in the region ${ }^{2}$. The investment activity indicates growth of regional commercial activity (primarily, mining), that led to regional production growth (see Figure 2$)^{3}$. The main object of the local investments in the YaNAO is the transport infrastructure because the region is positioned as one of the main Russian resource centres.

As for Finnmark, the economic viability of the region is determined by several factors. Primarily, the remoteness of the region from other Norwegian «commercial hubs» is not so considerable (comparing to Yamal and Russia) while logistic links are quite developed. Additionally, before

\footnotetext{
${ }^{1}$ Federal State Statistics Services. Retrieved from: https://eng. gks.ru/ (Date of access: 11.05.2019).

${ }^{2}$ Departament Ekonomiki Yamalo-Nenetskogo avtonomnogo okruga [Department of Economics of the YaNAO]. Retrieved from: https://de.yanao.ru/ (Date of access: 11.05.2019).

${ }^{3}$ According to the Russian Central Bank data the average exchange rate for the period from 2009 to 2019 is 10 NOK $\approx$ 63,1776 RUB.
}

mining activity, Finnmark had a well-established fishing industry that still represents substantial part of the regional economy. Nevertheless, the contribution of the Norwegian government towards economic development of the Nigh North territories cannot be overestimated. The consistent application of localization approach regarding diversification and support of regional and local businesses resulted in regional production's growth by $65 \%$ from 37 in 2009 to 61 bln NOK in $2016^{4}$ (see Figure 2). Consequently, the intensification of mining and relevant production has been followed by the surge in overall commercial.

Further, the development of cost-intensive mining projects resulted in intensive international commercial transactions in the regions, especially in the $\mathrm{YaNAO}^{5}$. Regional export has increased by 1.2 times due to deliveries of oil along the Northern Sea Route from the oil terminal Gates of the Arctic and gas from Yamal LNG. At the same time, a significant increase in the region's foreign trade turnover led to growth of import of machinery, equipment and vehicles (which share in total import exceeds $60 \%$ ) for the key Arctic projects, including Yamal LNG and the Northern Sea Route, by 2.6 times annually within 5 previous years. This fact confirms the aforementioned conclusion about Russia's lower industrial localization caused by import of expensive technologies and equipment.

\footnotetext{
${ }^{4}$ Regional Accounts. Statistics Norway. Retrieved from: https:// www.ssb.no/en/statbank/list/fnr (Date of access: 11.05.2019).

${ }^{5}$ Federal Customs Service. Retrieved from: http://eng.customs. ru (Date of access: 11.05.2019)
} 


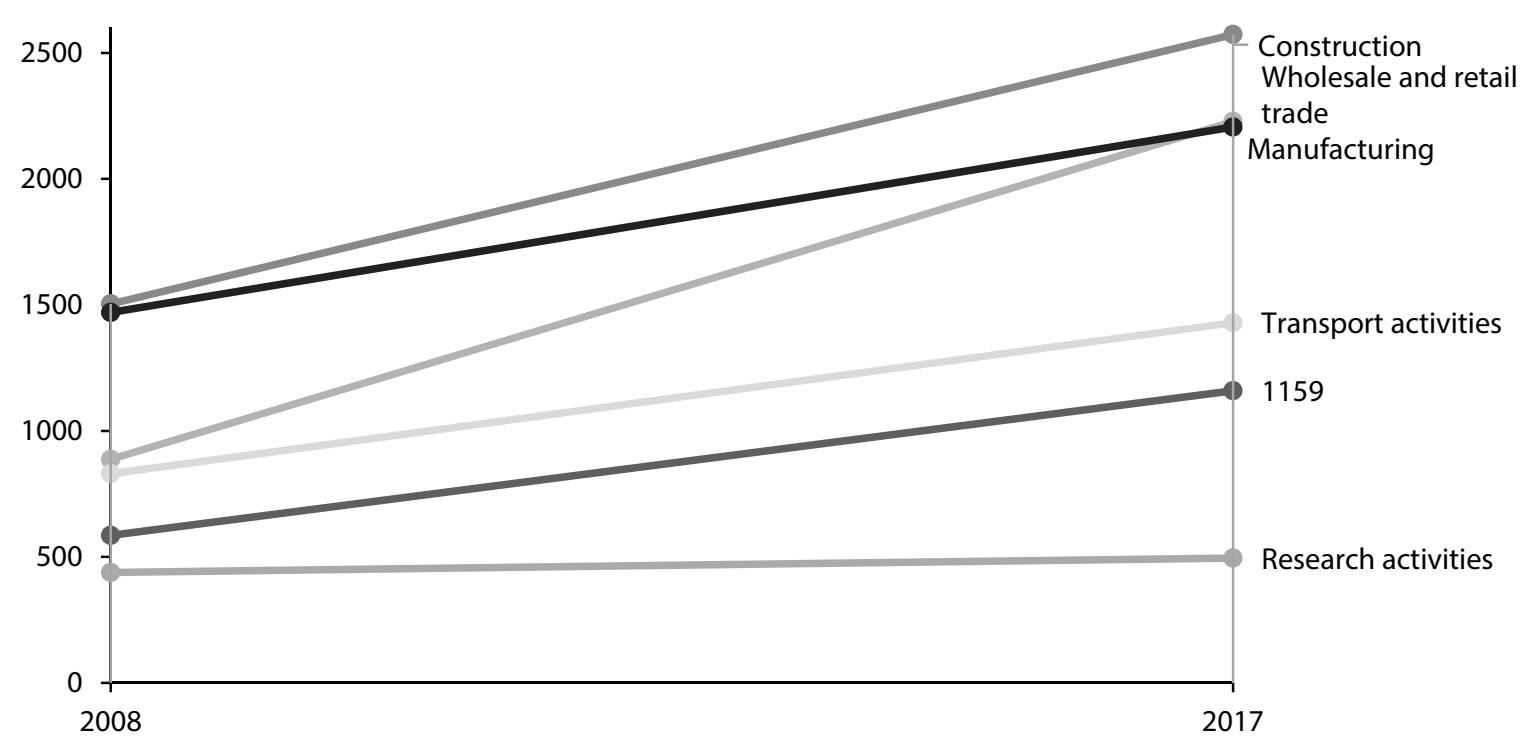

Fig. 3. Value added changes: from 2008 to 2017 in Finnmark (by industry), mIn NOK

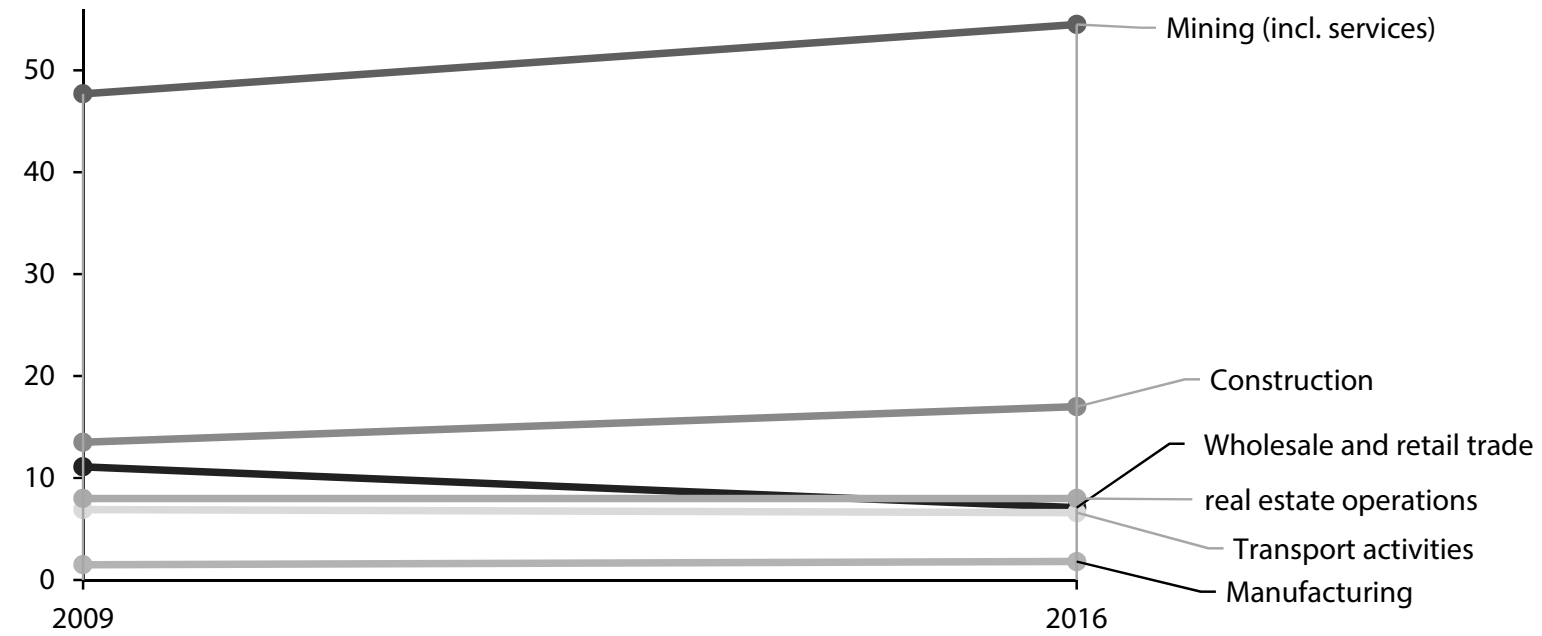

Fig. 4. Value added changes: from 2009 to 2016 in YaNAO (by industry), \%

Conversely, even though the main works in Snøhvit and Goliat were carried out by foreign contractors, the volume of supply services and works of local/regional businesses increased significantly during the project's development and production stages. Regional and mainly local companies received commercial offers for construction, transport and manufacturing [21]. This contracting policy resulted in rapid increase of value added generated within the region. In almost 10 years of the High North region's development, the value added created by Finnmark increased by $72 \%$. However, the most impressive results belong to manufacturing where value added increased by $151 \%$ from 2008 to 2017 (see Figure 4) ${ }^{1}$. Taking into account the fact that before launching petroleum projects the economic situation in Finnmark experienced a downturn, we may make a conclusion about positive ripple effects generated by re-

\footnotetext{
${ }^{1}$ Ibid.
}

inforcement of mining companies' operational activity.

As follows from Figure 3 and Figure 4, the application of comprehensive approach towards local content solutions (for instance, local procurement regulation and strategies) may contribute a lot to the regional development. Particularly, the Norwegian case with increased involvement of the local businesses resulted in diversification of the regional economy despite its small scale. At the same time, the YaNAO's experience shows that even large mining projects may fail to boost local industries' growth in case of poor local content despite the overall positive regional economic trends. Although the YaNAO's economy is based on the activities typical for the northern coastal regions, the high dynamic of the region's economic development is primarily caused by intensification of mining activities. Consequently, on the one hand, the YaNAO demonstrates growth of economic indicators. On the other hand, the 
absence of reasonable localization strategy led to disproportion in regional economy in favour of mining industry that generates major output. Additionally, the scenario of the socio-economic development elaborated by the Department of Economics of the YaNAO, predicts a positive trend for the key macroeconomic parameters that are expected to be generated mainly by the region's mining sector ${ }^{1}$.

The main problem Finnmark faces is similar to the situation observed in the YaNAO. More specifically, the analysis indicated an income gap between mining industry and other businesses as well as between municipality and the county. Along with the YaNAO, the coastal Norwegian regions such as Finnmark are characterised by high rates of socio-economic development determined by mining business. So, the major activities that traditionally underlined the competitiveness of coastal territories as marine industrial fishing, shipping, etc. still cannot compare with energy sector in terms of contribution to GRP and regional growth. The analysis of the YaNAO and Finnmark revealed that at local level incomings of households that are directly involved into oil and gas activity, are higher in comparison to others. For instance, due to the aspects of the offshore projects' development, the key economic benefits were mainly reaped by Hammerfest. The local budget was enriched by community. For example, during Snøhvit's development, the local budget gained more than $\$ 90$ million in form of property tax [22]. Therefore, the municipal authorities managed to build infrastructure and municipal facilities: educational institutions, administration buildings, cultural centres. The main businesses involved in the reconstruction were represented by local firms. Consequently, the income of households at local level significantly exceeded the average regional income ${ }^{2}$. As for the YaNAO, resource-based economy and mining activity of the key vertically integrated oil and gas companies also determined the welfare of the region and its important locations. For example, the towns of the YaNAO are characterised by the average income per capita that is twice higher than the average income in Russia. Thus, the statistical data confirms that mining-based economy without proper localization may lead to such negative implications as import growth and disbalance within the region.

\footnotetext{
${ }^{1}$ Departament Ekonomiki Yamalo-Nenetskogo avtonomnogo okruga [Department of Economics of the YaNAO]. Retrieved from: https://de.yanao.ru/ (Date of access: 11.05.2019).

${ }^{2}$ Regional Accounts. Statistics Norway. Retrieved from: https:// www.ssb.no/en/statbank/list/fnr (Date of access: 11.05.2019).
}

\section{Comparative Analysis of the Main Social Indicators}

As follows from the economic analysis, mining-oriented regional economies are characterised by growing indicators of economic development. However, the mining projects also exert strong influence on the region's social life. The field development and construction of production facilities are characterised by creation of significant number of temporary workplaces for local residents. However, after completion of all preparatory work, the number of jobs usually reduces. Additionally, the dependence on highly specialised monofunctional economy based on oil and gas activity leads to the absence of specialisation, well-developed manufacturing or high-tech industries. Consequently, development of extractive industry within one region could negatively affect this region's social sphere. This could be illustrated by the YaNAO case. The statistical data concerning social development of the YaNAO is contradictory and ambiguous. As we observe from the statistics, the regional population in the YaNAO is characterised by significant fluctuations and even negative trend in the last 7 years (see Figure 5) s. $^{3}$.

In addition, during the last years, the region's migration indicator has demonstrated population's decrease due to active immigration. To illustrate, in 2017 and 2016 the net migration in the YaNAO was -2418 and -3491 , respectively ${ }^{4}$. The analysis of the main reasons for the out-migration and population's decline revealed that beside climate conditions, the working population leaves the region due to (1) absence of reputable higher education institutes [23], (2) insufficient number of workplaces at non-oil and gas industries, and (3) completion of the construction phase of Yamal LNG project that required a huge amount of workforce only for a limited period.

At the same time, as Figure 5 shows, at the very beginning of the century Finnmark was characterised by low level of population caused by economic decrease and absence of any profitable commercial activity (except fishery). However, the initiation of oil and gas activity in the Barents Sea has significantly impacted the region and turned around the life of local inhabitants. From 2008 we could observe a positive trend in regional population in Finnmark. Figure 5 demonstrates the dependence of Finnmark's population growth on

\footnotetext{
${ }^{3}$ EMISS - Gosudarstvennaya statistika. Ofitsialnye statisticheskie pokazateli [UISIS - The Unified Interdepartmental Statistical Information System (UISIS) departmental information and statistical system]. Retrieved from: https://www.fedstat.ru/ (Date of access: 11.05.2019). ${ }^{4}$ Ibid.
} 


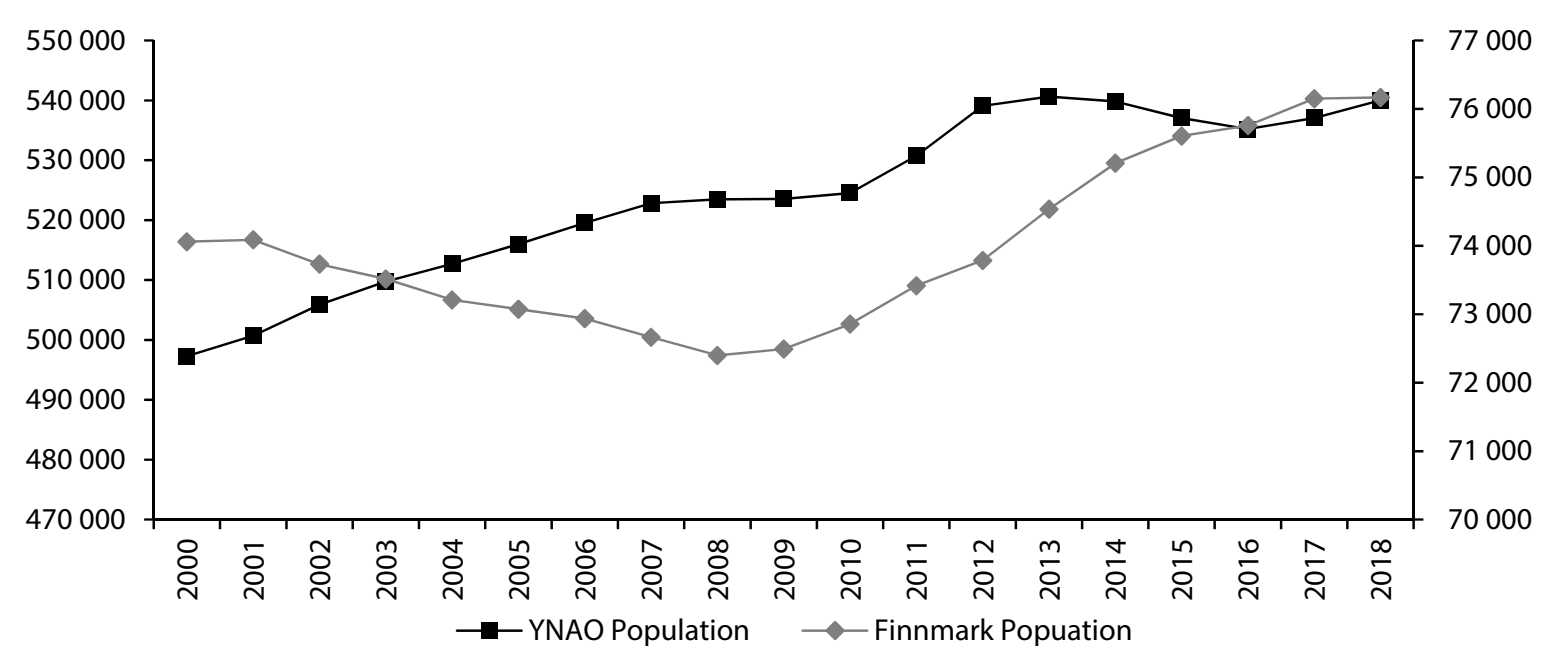

Fig. 5. Population changes in YANAO and Finnmark from 2000-2018, persons

stages of mining projects Snøhvit and Goliat ${ }^{1}$. The increase in population and migrants is important for the region from an economic point of view: increased number of locals indicates greater demand for goods, services and labour force in the interconnected industries. However, the experience of Finnmark differs from the YaNAO's one from labour statistics perspectives. In particular, a great number of regional employees are recruited not by mining companies, but by interconnected sectors. Particularly, about $60 \%$ of employees are recruited by «Wholesale and retail trade», «Education» and «Construction» ${ }^{2}$. Consequently, beside mining sector, the main services that were affected by the project's development in the region are represented by related industries. Despite the fact that the Snøhvit project had a significant part of foreign suppliers, a sharp increase in population provoked the increase in demand for goods and services provided by national suppliers. In the YaNAO we did not observe the same trends since the population's employment is still contingent on construction stages at fields and capacity of mining activity. The absence of strong links between related industries within the YaNAO as well as a grate share of imported goods and technologies negatively affect the social sphere. Additionally, the region's energy-oriented specialisation implies social differentiation and inequality. In accordance with the YaNAO's workforce statistics, oil and gas companies have more than $25 \%$ of workplaces, while education, whole and retail trade and construction all together comprise only $30 \%$ (which is two times less than in Norway).

\footnotetext{
${ }^{1}$ Ibid.

${ }^{2}$ Employed by residence and place of work. Statistics Norway. Retrieved from: https://www.ssb.no/en/statbank/list/fnr (Date of access: 11.05.2019).
}

Accordingly, the highest salary rates are also received by the mining employees, while the locals occupied in other industries generally receive salaries that are several times less. The observable unevenness of households' income within the region's population as well as distortions in favour of oil and gas sector determine social inequality and out-migration. However, such indicators as unemployment rate, intensity factor (correlation between the amount unemployed people and amount of job vacancies), as well as social inequality are significantly lower in the YaNAO in comparison to average country-level indicators ${ }^{3}$.

On the contrary, mining activity's intensification in Norway triggered the development of the region, which was peripheral from both geographical and economic perspectives. Unlike the YaNAO, Finnmark's key feature is the existence of economic diversification determined by smart economic management. Judging by the analysis of regulation of projects development, the main reasons of regional growth were the competent policy of the operator companies with regard to the local procurement, engagement of numerous related industries in the project as well as cooperation between businesses and municipal authorities. Hence, the region has become attractive not only for investments, but for employees from other towns and regions. The case of Finnmark demonstrates that the favourable conditions for localization created under cooperation of authorities and companies made unpromising project successful and led to the development of industries and growth of additional gross output.

While making conclusions based on the results of regional comparative research, we should bear

\footnotetext{
${ }^{3}$ Federal State Statistics Services. Retrieved from: https://eng. gks.ru/ (Date of access: 11.05.2019).
} 
in mind that the significant remoteness of the YaNAO from major Russian industries also hampers regional capability of increasing its localization. The key problem of the existing economic and social situation in the YaNAO is its inability to establish and develop interconnected industries and production despite the reinforcement of mining activity. The lack of local manufacturing businesses and low demand for local production led to paradoxical situation: population decreases while dependence on imported goods and services only increases. The underdevelopment of regional economy is partly explained by the fact that commercial impulses generated by the mining projects are not localized, so they do not reinforce the links with local/regional manufacturing. One of the explanations of the existing situation is the absence of terms determining the sustainable economic diversification. The existing inter-industrial links as well as overall level of industrial development do not allow implementation of the effective localization approach. So, new mining projects should ensure involvement of existing regional and national suppliers to the maximum possible extent.

\section{Recommendations and Conclusion}

The conducted analysis based on Input-Output model and index method has confirmed the paper's hypothesis. The development of large investment projects, especially in such remoted area as the High North, may comprise immense economic potential from domestic production's perspectives. Within the given scenario, the key to the economic growth lays in the comprehensive approach to project development with regard to its economic and social implications. As follows from our findings, this approach could be implemented if and only if the large involvement of domestic industries' goods and services as well as diversification of the region's economy underlie the project's development. In addition, the value chains within the country should be strong enough in order to enhance the overall effects of the project both at regional and national levels.

A closer look at aspects of the Hight North projects' development revealed several potential reasons of the Arctic projects' inability to meet the needs of the region. First of all, climate conditions imply cost-intensive nature of mining projects. So, operators usually prefer foreign suppliers that are more competitive in comparison with regional contractors. Secondly, the necessity to build infrastructure facilities may also drive mining companies out of the region or compel them to find alternative ways of equipping or sourcing transpor- tation from abroad. Finally, the overall insufficient macroeconomic development may also represent a burden for generation of ripple effects. So, the conflict of interests between revenue-oriented firms and socially-oriented authorities is obvious. Hence, nowadays only few examples of the Arctic projects succeeded in regional development due to comprehensive and complex approach towards project management along with existence of favourable economic environment.

Given the above, the main problem resides in striking a balance between mining companies' interests and common welfare. Primarily, it is up to authorities to ensure conditions that foster incentives for local supply growth. The increase of share of local procurement should be the focus of relevant enactments. Subsidising of national producers and imposition of constraints on foreign participation in the key projects may disrupt existing boundaries. In addition, technological inferiority and lack of competitiveness could be overcome by modified approach to scientific activity, implying strengthening of cooperation between national research centres and mining companies as well as adoption and examination of best practices under international cooperation. Of course, such measures should be adopted within the framework of the national economic system otherwise the implementation of occasional measures would not lead to expected results.

Following from the obtained conclusions, the appropriate procurement policy is a backbone for intensification of value chains. However, the efficient suppling strategy should rely on current state of the region. Regional authorities should determine the key problems, needs and requirements of local businesses and population as well as conditions underlying regional economic and social growth. Herewith, the officials may develop and set certain requirements for mining companies regulating their procurement policy. Next, the economic potential of the mining Arctic regions should be observed and estimated along with all existing industries as one system. Such cluster-based approach may determine effective mobilization of investments due to diversification and simultaneous development of knowledge-intensive industries. Finally, education should be considered as a key supporting sector that determines industrial diversification. Moreover, it should be perceived as an independent driver of economic growth. The regional educational sector may not only satisfy the local demand for low-specialised workers, but provide highly qualified specialists for the needs of the regional petroleum industry, create a competitive regional labour mar- 
ket and decrease the dependence on foreign labour force.

The current macroeconomic situation in Russia does not ensure efficient cooperation of the industries and its contracting policy is regulated inconsistently. Thus, the existing framework of project regulation fails to fulfil the basic principles of effective project management. In this research we determined the key problem that requires improvement, while our qualitative estimations and conclusions were reinforced by quantitative explications due to Input-Output model computations. In this regard, we can claim that, indeed, the investment projects may bring more benefits to domestic economy than they used to. However, in order to reap more benefits, the responsible authorities and companies have to update the current approach to project management in accordance with the needs of the domestic industries and sustainable development.

\section{References}

1. Lunden L. P. \& Fjørtoft D. (2014). Gosudarstvennya podderzhka dobychi nefti i gaza v Rossii. Rol subsidirovaniya $v$ razvitii proektov "Yamal SPG" I "Prirazlomnoe" [Government Support to Upstream Oil \& Gas in Russia. How Subsidies Influence the Yamal LNG and Prirazlomnoe Projects]. Imternational Institute for Sustainable Development, 58. Retrieved from: http://docplayer.ru/26430524-Gosudarstvennaya-podderzhka-dobychi-nefti-i-gaza-v-rossii.html (Date of access: 13.05.2019) (In Russ.)

2. Barbier, E. B. (2003). The Role of Natural Resources in Economic Development. Australian Economic Papers 42(2), 253-272. DOI: 10.1111/1467-8454.00198

3. Auty, R. M. (1993). Sustaining Development in Mineral Economies: The Resource Curse Thesis. London. New York: Routledge, 288. DOI: 10.4324/9780203422595

4. Sachs, J. D. \& Warner, A. M. (2001) Natural Resources and Economic Development: The curse of natural resources. European Economic Review, 45(4-6), 827-838. DOI: 10.1016/S0014-2921(01)00125-8.

5. Hoyos, C. (2010). Caudio Descalzi: «The days when groups could simply produce and export a country's oil are long gone». Financial Times. Retrieved from: https://www.ft.com/content/c08d2aee-78da-11df-a312-00144feabdc0 (Date of access: 11.05.2019).

6. Tordo, S., Warner, M., Manzano, O. E. \& Anouti, Y. (2013). Local Content Policies in the Oil and Gas Sector. World Bank Study, 173. Retrieved from: http://documents.worldbank.org/curated/en/549241468326687019/Local-content-in-theoil-and-gas-sector (Date of access: 08.05.2019).

7. Aoun, M.-C. \& Mathieu, C. (2015). Local content strategies in the oil and gas sector: How to maximise benefits to host communities. IFRI/IGU, Center for Energy, 19. Retrieved from: https://www.ifri.org/sites/default/files/atoms/files/local_ content_tf3_igu_final_may_2015.pdf (Date of access: 11.05.2019).

8. Tordo, S., Tracy, B. S. \& Arfaa, N. (2011). National Oil Companies and Value Creation. World Bank Working Paper 218, World Bank, Washington, DC, Volume 3, 127. Retrieved from: http://siteresources.worldbank.org/INTOGMC/Resources/ noc_volume_III.pdf(Date of access: 08.05.2019).

9. IPIECA, (2011). Local Content Strategy: A Guidance Document for the Oil and Gas Industry. Retrieved from: http://www.ipieca.org/umbraco/Surface/Media/Download?url=\%2fmedia\%2f1970\%2flocal_content.pdf (Date of access: 08.05.2019).

10. Anchondo, D. J. (2010). Local content requirements in the oil and gas sector: a way of life or an emerging trend? Oil and gas law newsletter, 1(1), 15-18.

11. Albala-Betrand, J. M. (2009). Globalization and Localization: An Economic Approach. In: H. Rodriguez, E. L. Quarantelli, R. R. Dynes (Eds.), Handbook of Disaster Research (pp. 147-167). New York, NY, Springer. DOI: 10.1007/978-0387-32353-4_9.

12. Jovanova, K. (2017). Globalization Versus Localization - Economic Development Perspectives. European Journal of Sustainable Development, 6(3), 181-188. DOI: 10.14207/ejsd.2017.v6n3p181.

13. Esteves, A. M., Coyne, B. \& Moreno, A. (2013). Local Content Initiatives: Enhancing the Subnational Benefits of the Oil, Gas and Mining Sectors. Revenue Watch Institute Briefing, July. New York, NY: Natural Resource Governance Institute, 28. Retrieved from: https://resourcegovernance.org/sites/default/files/Sub_Enhance_Benefits_20151125.pdf (Date of access: 11.05.2019)

14. Goridko, N. \& Nizhegorodtsev, R. (2018). Tochki rosta regionalnoy ekonomiki i regressionnaya otsenka otraslevykh investitsionnykh multiplikatorov [The Growth Points of Regional Economy and Regression Estimation for Branch Investment Multipliers]. Ekonomika regiona [Economy of region], 14(1), 29-42. DOI: 10.17059/2018-1-3 (In Russ.)

15. Serikov, P. Y., Korneeva, S. V. \& Petrova Y. A. (2014). Otsenka investitsionnykh proektov s tochki zreniya obshchestvennoy effektivnosti s uchetom multiplikativnykh effektov [Evaluation of investment projects from the point of view of public efficiency in reliance on multiplicative effects]. Nauka i tekhnologii truboprovodnogo transporta nefti i nefteproduktov [Science \& Technologies: Oil and Oil Products Pipeline Transportation], 3(15), 108-115. DOI: 10.15862/59EVN216 (In Russ.)

16. Shirov, A. A. \& Yantovskiy, A. A. (2011). Otsenka multiplikativnykh effektov v ekonomike. Vozmozhnosti i ogranicheniya [Ripple effects estimation in the economy: opportunities and limitations]. ECO [EKO], 2, 40-58. (In Russ.) 
17. Dobbs, R., Oppenheim, J. \& Kendall, A. (2013). Reverse the Curse: Maximising the Potential of Resource-Driven Economies. McKinsey Global Institute. Retrieved from: https://www.mckinsey.com/industries/metals-and-mining/our-insights/reverse-the-curse-maximizing-the-potential-of-resource-driven-economies (Date of access: 11.05.2019)

18. Developing Local Content Programs - Insights from Accenture for Global Players to Achieve High Performance in Today's Competitive Energy Landscape. (2008). Acccenture. Retrieved from: https://www.criticaleye.com/insights-servfile. cfm?id=833. (Date of access: 09.05.2019)

19. Kryukov, V. A. \& Tokarev, A. N. (2007). Neftegazovye resursy v transformiruemoy ekonomike: o sootnoshenii realizovannoy i potentsialnoy obshchestvennoy tsennosti nedr (teoriya, praktika, analiz i otsenka) [Oil-and-Gas Resources in a Transitional Economy: Comparing realized and potential social Value of Mineral Wealth (Theory, Practice, Analysis, and Estimates)]. Novosibirsk: Nauka-Tsentr, 588. (In Russ.)

20. Fjærtoft, D. B. (2015). Modeling Russian regional economic ripple effects of the oil and gas industry: Case study of the republic of Komi. Regional Research of Russia, 5(2), 109-121. DOI: 10.1134/S2079970515020033.

21. Loe, J. \& Kelman, I. (2016). Arctic petroleum's community impacts: local perceptions from Hammerfest, Norway. Energy Research \& Social Science, 16, 25-34.

22. Eikland, S. (2014). Building a High North Growth Pole: The Northern Norwegian City of Hammerfest in the Wake of Developing the «Snow White» Barents Sea Gas Field. Journal of Rural and Community Development, 1(9), 66-67

23. Suptelo, N. P. (2018). Osobennosti ekonomicheskogo razvitiya Yamalo-Nenetskogo avtonomnogo okruga i ikh vliyanie na sotsialnyy sfery regiona [Yamalo-Nenets Autonomous District economic development and its influence to social sphere]. Vestnik universiteta imeni S. Yu. Vitte. Seriya 1: Ekonomika i upravlenie [Moscow Witte University Bulletin. Series 1: Economics and Management], 3(26), 47-53. DOI: 10.21777/2587-554X-2018-3-47-53 (In Russ.)

\section{Authors}

Daria Mikhaylovna Kolesnikova - PhD student, Faculty of World Economy and International Affairs, National Research University Higher School of Economics; ORCID: 0000-0003-0166-9083 (11, Pokrovsky Boul., Moscow, 109028, Russian Federation; e-mail: dmkolesnikova@yandex.ru).

Olga Vasilevna Noshchenko - PhD student, Faculty of World Economy and International Affairs, National Research University Higher School of Economics; ORCID: 0000-0002-9653-0748 (11, Pokrovsky Boul., Moscow, 109028, Russian Federation; e-mail: olga.noshchenko@gmail.com).

Valeriy Anatolevich Kryukov - Director, Institute of Economics and Industrial Engineering of the Siberian Branch of RAS, Member of RAS; Professor, Doctor of Economics; Head of the Energy and Resource Markets Department, Faculty of World Economy and International Affairs, National Research University Higher School of Economics Scopus Author ID: 7004906327; ORCID: 0000-0001-8535-0568 (17, Akademika Lavrentieva St., Novosibirsk, 630090; 17, Malaya Ordynka St., Moscow, 119017, Russian Federation; e-mail: kryukov@ieie.nsc.ru). 